\title{
MODEL SISTEM INFORMASI RISALAH LELANG DI KANTOR PELAYANAN KEKAYAAN NEGARA DAN LELANG KOTA CIREBON DENGAN METODE CLUSTERING ALGORITMA C45
}

\author{
Rini Astuti ${ }^{1}$ \\ Nurhidayat $^{2}$ \\ Sekolah Tinggi Manajemen Informatika dan Komputer LIKMI \\ Jl. Ir. H. Juanda 96 Bandung 40132 \\ E-mail : \\ riniastuti@likmi.ac.id ${ }^{1}$ \\ hidayatnfatmayan@gmail.com²
}

\begin{abstract}
ABSTRAK
Risalah lelang merupakan berita acara, informasi proses pelelangan atau akta otentik dengan kekuatan pembuktian sempurna yang dibuat oleh pejabat lelang dari pembelian suatu barang melalui proses lelang. Risalah lelang juga dapat digunakan dalam membantu mencari informasi pemenang lelang, ataupun banyaknya barang yang tidak terjual, barang yang berhasil terjual maupun jenis barang yang paling banyak terjual dalam proses lelang. Sistem Informasi Risalah Lelang merupakan suatu kumpulan dari komponen-komponen dalam perusahaan atau organisasi yang berhubungan dengan proses penciptaan dan pengaliran informasi tentang risalah lelang atau berita acara proses lelang.

Pengembangan sistem informasi risalah lelang berbasis web menerapkan pengelompokan dengan menggunakan Algoritma C45 dengan metode clustering, clustering merupakan proses yang digunakan untuk mengelompokkan objek sesuai informasi yang diperoleh dari data yang menyamakan anggota dalam kelasnya. Pendekatan proses pengembangan yang digunakan adalah pendekatan berorientasi objek dengan tool UML dengan model proses prototyping.

Melalui sistem ini, dapat memudahkan proses pencarian informasi risalah lelang pada Kantor Kekayaan Negara dan Lelang kota Cirebon. Serta dapat memudahkan dalam penyajian informasi berupa data lelang terbanyak dan sebagainya, juga mampu meningkatkan kualitas kerja pegawai dalam hal pemanfaatan waktu dan meningkatkan pelayanan.
\end{abstract}

Kata kunci : Risalah Lelang, Prototyping, Algoritma C45

\section{PENDAHULUAN}

Proses lelang diketahui sebagai proses jual beli barang dengan cara menawarkan kepada calon pembeli dengan harga tawaran tertinggi. Proses mengajukan tawaran dilakukan secara berulang, calon pembeli yang menawar barang dengan harga tertinggi dinyatakan sebagai pemenang lelang.

Informasi proses pelelangan, berita acara lelang dan fakta dari proses tawar menawar diistilahkan sebagai risalah lelang. Jika proses lelang dilakukan secara terus meneus dengan jenis barang dan lokasi yang beragam tentu membutuhkan upaya yang cukup lama untuk pencarian pemenang, lokasi lelang, jadwal lelang dan informasi lainnya sesuai kebutuhan daerah. 
Dengan menggunakan metode clustering proses pencarian informasi risalah lelang dapat lebih mudah dilakukan, metode clustering yaitu salah satu teknink statistik yang bertujuan mengelompokkan objek kedalam satu kelompok sehingga objek yang berada dalam satu kelompok akan memiliki kesamaan yang tinggi dibandingkan dengan objek yang berada di kelompok lain.

Dalam kasus ini, sistem informasi risalah lelang yang dibuat menerapkan metode clustering algoritma $\mathrm{C} 45$ yang membutuhkan analisis data yang bertujuan untuk mengelompokkan data dengan karakteristik yang sama kesatu wilayah yang sama dan data dengan karakteristik berbeda ke wilayah yang lain.

\subsection{Ruang Lingkup}

Ruang lingkup dari penelitian yang dibahas adalah sebagai beikut :

a. Menganalisis kondisi Sistem Informasi Risalah Lelang Di Kantor Pelayanan Kekayaan Negara Dan Lelang Kota Cirebon yang sedang berjalan.

b. Membangun Sistem Informasi Risalah Lelang Di Kantor Pelayanan Kekayaan Negara Dan Lelang Kota Cirebon dengan menerapkan metode clustering algoritma C45 untuk mempermudah penyajian informasi risalah lelang sesuai dengan kebutuhan.

\subsection{Tujuan Penelitian}

Tujuan dilaksanakannya penelitian adalah :

a. Merancang sistem informasi risalah lelang dengan alat bantu berorientasi objek .

b. Memudahkan pencarian informasi dengan menerapkan algoritma C45 menggunakan metode clustering untuk sistem informasi risalah lelang pada Kantor Pelayanan Kekayaan Negara dan Lelang.

\section{LANDASAN TEORI}

\subsection{Model Prototyping}

Perencanaan iterasi pembuatan prototipe dilakukan secara cepat. Setelah itu dilakukan pemodelan dalam bentuk "rancangan cepat". Pembuatan rancangan cepat berdasarkan pada representasi aspek-aspek perangkat lunak yang akan terlihat oleh para end user (misalnya rancangan antarmuka pengguna atau format tampilan). Rancangan cepat merupakan dasar untuk memulai konstruksi pembuatan prototipe.

Menurut Pressman [5], model prototyping dimulai dari tahap komunikasi. Tim pengembang melakukan pertemuan dengan para stakeholder untuk menentukan kebutuhan sistem yang saat itu diketahui dan untuk menggambarkan area-area dimana definisi kebutuhan ditentukan untuk iterasi selanjutnya.

Prototipe kemudian diserahkan kepada para stakeholder untuk mengevaluasi prototype yang telah dibuat sebelumnya dan memberikan umpan-balik yang akan digunakan untuk memperbaiki spesifikasi kebutuhan. Iterasi terjadi saat pengembang melakukan perbaikan terhadap prototipe tersebut. 


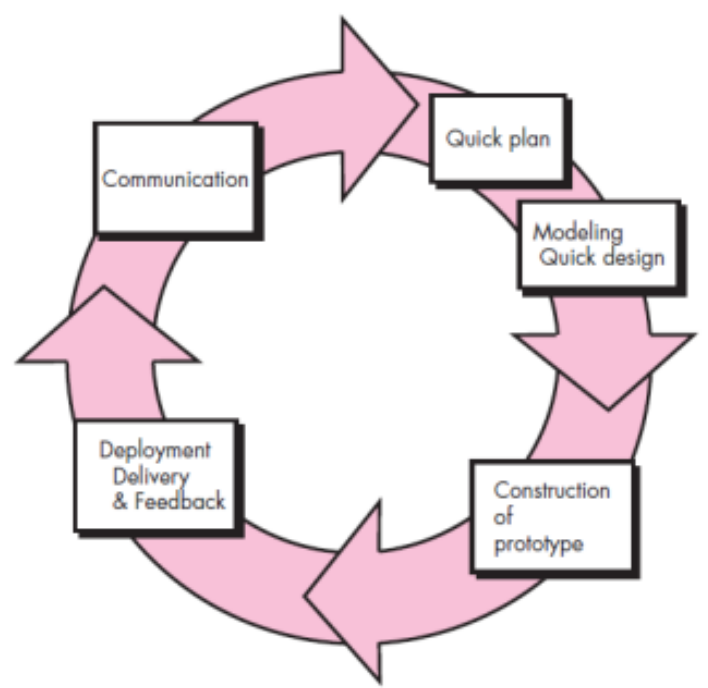

Gambar 1

Model prototyping

(Pressman, 2010)

\subsection{Algoritma C45}

Metode clustering adalah salah satu proses data mining untuk pengelompokan. Terdapat berbagai jenis pengelompokan diantaranya adalah K-means dan Algoritma C45. Algoritma C45 atau pohon keputusan digunakan untuk menghasilkan pohon keputusan dan aturan klasifikasi data yang dapat mendeteksi hubungan antara variabel input dan menghasilkan output berdasarkan pola observasi data [1].

Pada dasarnya konsep dari algoritma $\mathrm{C} 4.5$ adalah mengubah data menjadi pohon keputusan dan aturan-aturan keputusan (rule). C4.5 adalah algoritma yang cocok untuk masalah klasifikasi dan data mining. C4.5 memetakan nilai atribut menjadi kelas yang dapat diterapkan untuk klasifikasi baru [2].

Pohon keputusan merupakan koleksi node yang membentuk pohon biner seperti kutipan berikut : A decision tree is a collection of nodes, arranged as a binary tree. The leaves render decisions; in our case, the decision would be "likes" or "doesn't like." [3]

Ada beberapa tahapan dalam membangun sebuah pohon keputusan dengan algoritma C45 yaitu menyiapkan data training, biasanya diambil dari data histori yang pernah terjadi sebelumnya dan sudah dikelompokkan kedalam kelas-kelas tertentu, kemudian dilanjutkan dengan menentukan akar pohon. Akar akan diambil dari atribut yang paling tinggi yang akan menjadi akar pertama, dan langkah selanjutnya ialah menghitung nilai gain dari atribut, sebelum menghitug gain hitung dahulu nilai entropi.

Untuk menghitung nilai entropi digunakan rumus :

$\operatorname{Entropy}(S)=\sum^{\mathrm{N}_{\mathrm{i}}}=1-p i \log 2 p i$

$\mathrm{S}=$ Himpunan kasus

$\mathrm{N}=$ Jumlah partisi $\mathrm{S}$

$\mathrm{Pi}=$ Proporsi Si terhadap S

Kemudian hitung nilai gain menggunakan rumus :

$\operatorname{Gain}(S . A)=\operatorname{Entropy}(S)-\sum_{i}{ }_{i}=\frac{[S i \mid}{S} * \operatorname{Entropy}(S i)$

$\mathrm{S}=$ Himpunan kasus

$\mathrm{A}=$ Fitur 
$\mathrm{n}=$ Jumlah partisi atribut A

$|\mathrm{Si}|=$ Proporsi Si terhadap S

$|\mathrm{S}|=$ Jumlah kasuh dalam $\mathrm{S}$

Ulangi langkah penentuan akar pohon hingga semua record terpartisi, proses berhenti saat semua record dalam simpul $\mathrm{N}$ mendapat kelas yang sama, tidak ada atribut didalam record yang dipartisi lagi dan tidak ada record didalam cabang yang kosong.

\subsection{Clustering}

Clustering atau klasterisasi merupakan pengkelompokan record, didalam buku karya suyanto yang berjudul "Data Mining Untuk Klasifikasi dan Klasterisasi Data" menjelaskan :

"Pada data tertentu, teknik klasterisasi atau clustering biasa digunakan untuk mereduksi data. Ide dasarnya sangatlah sederhana, objek data dipartisi kedalam sejumlah kelompok atau cluster dimana objek-objek yang sangat mirip dikelompokkan kedalam klaster yang sama sedangkan objek-objek yang berbeda di klaster yang berbeda".[6]

Di dalam buku "Minning of Massive Datasets" karya Lescovec Jure et al. [3] menjelaskan :

"Clustering is the process of examining a collection of "points," and grouping the points into "clusters" according to some distance measure. The goal is that points in the same cluster have a small distance from one another, while points in different clusters are at a large distance from one another". [3]

Dijelaskan bahwa clustering adalah proses pengujian sekelompok titik dan mengelompokkan titik ke dalam cluster berdasarkan jarak. Tujuannya adalah mencari jarak terdekat akan memiliki cluster yang sama sementara jarak lainnya dengan cluster berbeda.

\subsection{Lelang dan Risalah Lelang}

Lelang merupakan penjualan barang yang terbuka untuk umum dengan penawaran harga secara tertulis dan atau lisan yang semakin meningkat atau menurun untuk mencapai harga tertinggi, yang didahului dengan Pengumuman Lelang. ( Pasal 1 angka 1 Peraturan Menteri Keuangan Nomor 27/PMK.06/2016 tentang Petunjuk Pelaksanaan Lelang "Permenkeu 27/2016").

Pada dasarnya terdapat beberapa jenis lelang yaitu sebagai berikut :

a. Lelang Eksekusi

Adalah lelang untuk melaksanakan putusan atau penetapan pengadilan, dokumendokumen yang dipersamakan dengan itu, dan atau melaksanakan ketentuan dalam peraturan perundang-undangan.( Pasal 1 angka 4 Permenkeu 27/2016).

b. Lelang Non Eksekusi Wajib

Adalah lelang untuk melaksanakan penjualan barang yang oleh peraturan perundang-undangan diharuskan dijual secara lelang.(Pasal 1 angka 5 Permenkeu 27/2016).

c. Lelang Non Eksekusi Sukarela

Adalah lelang atas barang milik swasta, perseorangan atau badan hukum / badan usaha yang dilelang secara sukarela.(Pasal 1 angka 6 Permenkeu 27/2016).

Risalah Lelang adalah berita acara pelaksanaan lelang yang dibuat oleh Pejabat Lelang yang merupakan akta otentik dan mempunyai kekuatan pembuktian sempurna. [4]. Risalah Lelang berbentuk dokumen laporan, merupakan produk hukum Pejabat Lelang statusnya sama dengan akta otentik karena memenuhi syarat-syarat sebagai suatu akta otentik seperti yang diatur dalam Pasal 1868 Kitab Undang-Undang Hukum Perdata. 


\section{METODOLOGI DAN PEMBAHASAN}

\subsection{Metodologi}

Penelitian ini bersifat kualitatif dengan melakukan observasi (Participant Observation) dalam observasi ini, melihat kejadian proses lelang secara langsung di Kantor Pelayanan Kekayaan Negara dan Lelang, atau yang digunakan sebagai sumber data penelitian. Dengan observasi ini, maka data yang diperoleh akan lebih lengkap, tajam, dan sampai mengetahui pada tingkat makna dari setiap perilaku yang nampak dan menyajikan data dalam bentuk angka atau persentase, kemudian data diolah menggunakan metode clustering dengan Algoritma C45.

\subsection{Pembahasan}

\subsubsection{Analisis Sistem}

Tahap ini didentifikasi sistem yang sedang berjalan melalui survey dan wawancara. Saat ini aplikasi pada Kantor Pelayanan Kekayaan Negara dan Lelang kota Cirebon masih belum ada menu khusus untuk laporan proses lelang, khususnya informasi seputar risalah lelang.

Risalah lelang sendiri ialah berita acara atas pelaksanaan lelang yang dibuat oleh pejabat lelang serta merupakan bukti atau akta otentik dan mempunyai kekuatan pembuktian sempurna, namun pelaporannya dilapangan masih menggunakan program seperti Ms.Excel sehingga untuk mengolah data agar didapatkan informasi risalah lelang sesuai dengan kebutuhan masih membutuhkan waktu yang cukup lama dalam pengolahan datanya.

Penerapan metode clustering dengan algoritma C45 dapat mendukung kebutuhan informasi bagi Sistem Informasi Risalah Lelang di Kantor Pelayanan Kekayaan Negara dan Lelang Kota Cirebon.

\subsubsection{Pemodelan Fungsional}

Alat bantu yang digunakan untuk memodelkan fungsional sistem ini adalah use case diagram. Pemodelan fungsional dibuat berdasarkan kondisi sistem yang sedang berjalan saat ini dan kebutuhan sistem sehingga proses lelang dan kebutuhan informasi dapat terpenuhi secara efisien dan efektif.

Aktor yang terlibat pada use case Bisnis adalah Pemohon, Pembeli, Seksi Pelayanan Lelang dan Pejabat Lelang sedangkan pada Sistem use case adalah user dan Admin.

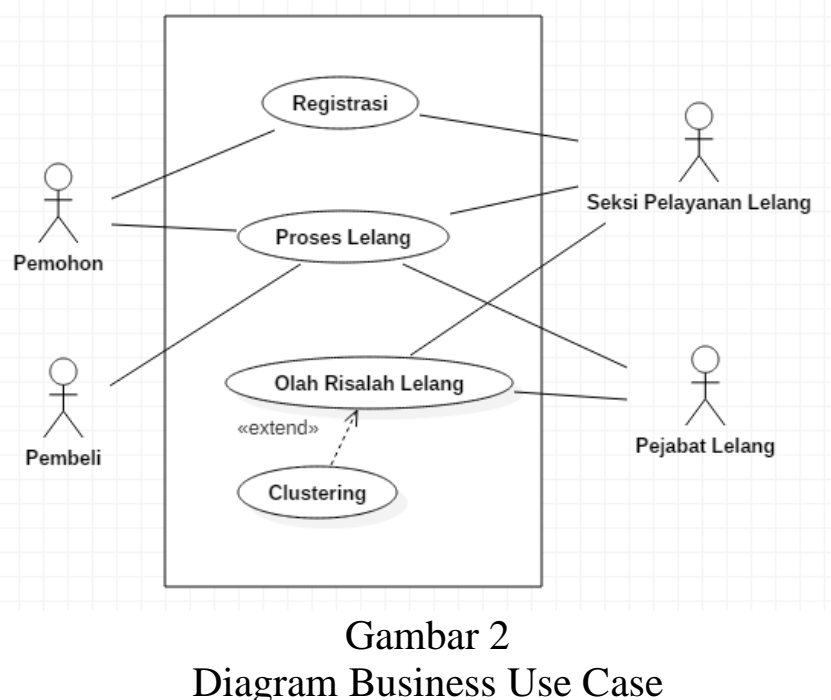




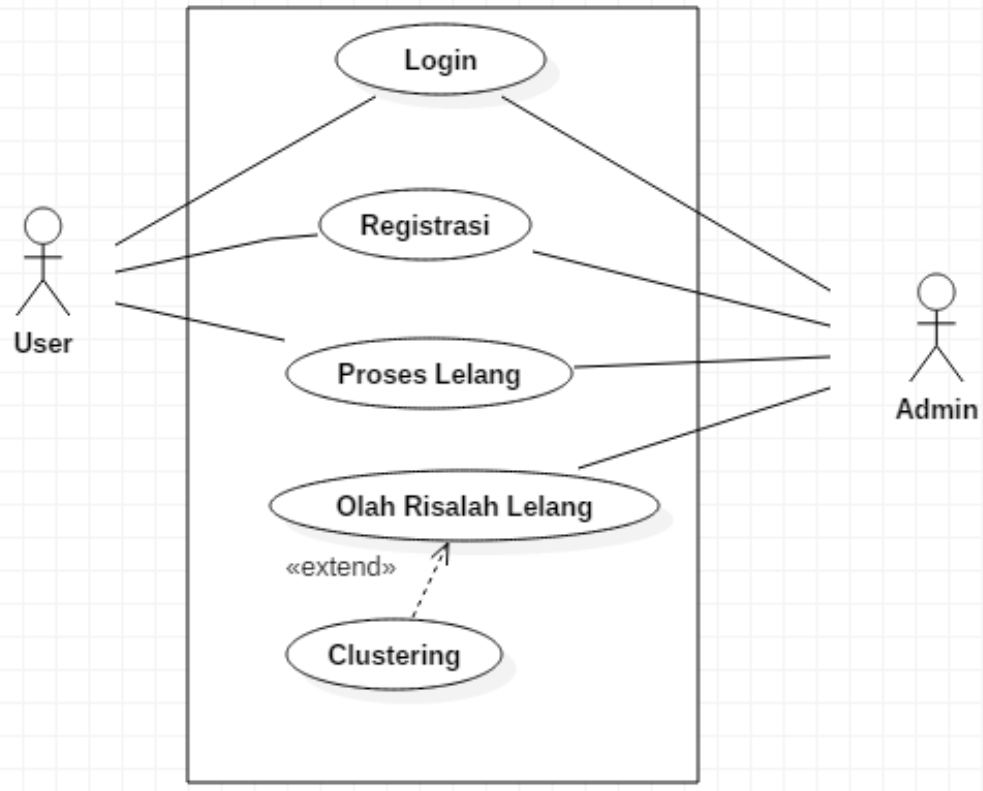

Gambar 3

Diagram System Use Case

\subsubsection{Proses Clustering}

Ada beberapa tahapan dalam membangun sebuah pohon keputusan dengan algoritma C45 yaitu menyiapkan data training, biasanya diambil dari data histori yang pernah terjadi sebelumnya dan sudah dikelompokkan kedalam kelas-kelas tertentu, kemudian dilanjutkan dengan menentukan akar pohon. Akar akan diambil dari atribut yang paling tinggi yang akan menjadi akar pertama, dan langkah selanjutnya ialah menghitung nilai gain dari atribut, sebelum menghitug gain hitung dahulu nilai entropi. Ulangi langkah penentuan akar pohon hingga semua record terpartisi, proses berhenti saat semua record dalam simpul $\mathrm{N}$ mendapat kelas yang sama, tidak ada atribut didalam record yang dipartisi lagi dan tidak ada record didalam cabang yang kosong.

Untuk memudahkan penjelasan tentang algoritma $\mathrm{C} 45$, berikut ini disertakan contoh kasus yang tercantum pada Tabel 1 .

Tabel 1 Keputusan Status Lelang

\begin{tabular}{|c|c|c|c|c|c|c|l|}
\hline $\begin{array}{c}\text { NO. } \\
\text { REG }\end{array}$ & HPKB & $\begin{array}{c}\text { NO. } \\
\text { RISALAH } \\
\text { LELANG }\end{array}$ & $\begin{array}{c}\text { NO. LOT } \\
\text { BARANG }\end{array}$ & $\begin{array}{c}\text { REGIS } \\
\text { BATAL }\end{array}$ & PEMBELI & PELUNASAN & $\begin{array}{c}\text { STATUS } \\
\text { LELANG }\end{array}$ \\
\hline 128 & 455 & 413 & 1 & & 3209141808630000 & 18 April 2017 & LAKU \\
\hline 089 & 330 & 411 & 1 & & & & TAP \\
\hline 75 & 269 & 410 & 1 & & & & TAP \\
\hline 75 & 268 & 409 & 8 & & & & TAP \\
\hline 134 & 469 & 412 & 17 & & 3209151604810003 & & WANPRESTASI \\
\hline 172 & 596 & 719 & 3 & & & & TAP \\
\hline 172 & 597 & 720 & 1 & & & & TAP \\
\hline 172 & 598 & 721 & 1 & & & & TAP \\
\hline 172 & 599 & 722 & 1 & & 3209286006630000 & 27 Juli 2017 & LAKU \\
\hline 172 & 600 & 723 & 4 & & & & TAP \\
\hline 172 & 602 & 724 & 1 & & & & TAP \\
\hline
\end{tabular}




\begin{tabular}{|c|c|c|c|c|c|c|l|}
\hline $\begin{array}{c}\text { NO. } \\
\text { REG }\end{array}$ & HPKB & $\begin{array}{c}\text { NO. } \\
\text { RISALAH } \\
\text { LELANG }\end{array}$ & $\begin{array}{c}\text { NO. LOT } \\
\text { BARANG }\end{array}$ & $\begin{array}{c}\text { REGIS } \\
\text { BATAL }\end{array}$ & PEMBELI & PELUNASAN & $\begin{array}{l}\text { STATUS } \\
\text { LELANG }\end{array}$ \\
\hline 175 & 613 & 603 & 1 & & 3175081606530003 & 09 Juni 2017 & LAKU \\
\hline 171 & 586 & 604 & 1 & & & & TAP \\
\hline 124 & 449 & 402 & 1 & & & & TAP \\
\hline 155 & 526 & 684 & 1 & & 3212062008870002 & 19 Juli 2017 & LAKU \\
\hline 155 & 521 & 679 & 1 & & & & TAP \\
\hline 155 & 523 & 680 & 1 & & & & TAP \\
\hline 155 & 524 & 681 & 1 & & & & TAP \\
\hline 155 & 525 & 682 & 1 & & & & TAP \\
\hline 155 & 522 & 683 & 1 & & & & TAP \\
\hline
\end{tabular}

Dalam kasus yang tertera dalam Tabel 1 akan dibuat pohon keputusan untuk menentukan status lelang apakah tidak ada penawaran (TAP), LAKU, BATAL atau WANPRESTASI dengan melihat keadaan apakah ada nomor register, hasil penelitian kelegkapan barang (HPKB), nomor regis batal, data pembeli dan pelunasan / pembayaran lelang. berikut.

Secara umum algoritma C45 untuk membangun pohon keputusan adalah sebagai

a. Pilih atribut sebagai akar.

b. Buat cabang untuk tiap-tiap nilai.

c. Bagi kasus dalam cabang.

d. Ulangi proses untuk setiap cabang sampai smua kasus pada cabang memiliki kelas yang sama.

Untuk memilih atribut sebagai akar, diambil berdasarkan nilai gain tertinggi dari atribut-atribut yang ada. Penjelasan lebih terperinci untuk langkah-langkah pembentukan pohon keputusan dengan menggunakan algoritma $\mathrm{C} 45$ untuk menyelesaikan permasalahan pada tabel 1 sebagai berikut.

Menghitug jumah kasus, jumlah kasus untuk keputusan LAKU, jumlah kasus untuk keputusan TAP, jumlah kasus untuk keputusan WANPRESTASI, jumah kasus untuk keputusan BATAL dan Entropy dari semua kasus dan kasus yang dibagi berdasarkan atribut No.Regis, HPKB, Reg.Batal,Pembeli dan Pelunasan, setelah itu lakukan perhitungan gain untuk setiap atribut, hasil perhitungan ditunjukkan pada tabel 2.

Tabel 1

Perhitungan Node 1

\begin{tabular}{|c|c|c|c|c|c|c|c|c|}
\hline & & $\begin{array}{l}\text { JML } \\
\text { KASUS } \\
\text { (S) }\end{array}$ & $\begin{array}{l}\text { LAKU } \\
\text { (S1) }\end{array}$ & $\begin{array}{l}\text { TAP } \\
\text { (S2) }\end{array}$ & $\begin{array}{l}\text { WAN } \\
\text { PRESTASI } \\
\text { (S3) }\end{array}$ & BATAL (S4) & ENTROPY & GAIN \\
\hline TOTAL & & 20 & 4 & 15 & 1 & 0 & 0,991760148 & \\
\hline \multirow[t]{3}{*}{ NO. REGIS } & & & & & & & & 0 \\
\hline & Ada & 20 & 4 & 15 & 1 & 0 & 0,991760148 & \\
\hline & Tidak ada & 0 & 0 & 0 & 0 & 0 & 0 & \\
\hline \multirow[t]{3}{*}{ HPKB } & & & & & & & & 0 \\
\hline & Ada & 20 & 4 & 15 & 1 & 0 & 0,991760148 & \\
\hline & Tidak ada & 0 & 0 & 0 & 0 & 0 & 0 & \\
\hline
\end{tabular}




\begin{tabular}{|l|l|r|r|r|r|r|r|r|}
\hline & & $\begin{array}{c}\text { JML } \\
\text { KASUS } \\
\text { (S) }\end{array}$ & $\begin{array}{c}\text { LAKU } \\
\text { (S1) }\end{array}$ & $\begin{array}{c}\text { TAP } \\
\text { (S2) }\end{array}$ & $\begin{array}{c}\text { WAN } \\
\text { PRESTASI } \\
\text { (S3) }\end{array}$ & BATAL (S4) & ENTROPY & GAIN \\
\hline REG BATAL & & & & & & & & 0 \\
\hline & Ada & 0 & 0 & 0 & 0 & 0 & 0 & \\
\hline & Tidak ada & 20 & 4 & 15 & 1 & 0 & 0,991760148 & \\
\hline PEMBELI & & & & & & & & 0,811278 \\
\hline & Ada & 5 & 4 & 0 & 1 & 0 & 0,721928095 & \\
\hline & Tidak ada & 15 & 0 & 15 & 0 & 0 & 0 & \\
\hline PELUNASAN & & & & & & & 0 & 0,721928 \\
\hline & Ada & 4 & 4 & 0 & 0 & 0 & 0 & \\
\hline & Tidak ada & 16 & 0 & 15 & 1 & 0 & 0,337290067 & \\
\hline
\end{tabular}

Baris TOTAL kolom Entropy pada tabel 2 Perhitungan Node1 dihitung dengan perhitungan berikut :

$$
\begin{aligned}
& \text { Entropy }(\text { TOTAL })=\left(-\frac{4}{20} * \log _{2}\left(\frac{4}{20}\right)\right)+\left(-\frac{15}{20} * \log _{2}\left(\frac{15}{20}\right)\right)+\left(-\frac{1}{20} * \log _{2}\left(\frac{1}{20}\right)\right) \\
& \text { Entropy }(\text { TOTAL })=0,991760148
\end{aligned}
$$

Sementara untuk nilai Gain pada baris No.Regis dihitung dengan menggunakan rumus perhitungan sebagai berikut

$$
\begin{aligned}
& \text { Gain (Total, No.Regis) }=\text { Entropy }(\text { Total })-\sum_{\mathrm{i}}{ }_{\mathrm{i}}{ }_{1} \frac{\mid \text { No.Regis }]}{[\text { Total }]} * \text { Entropy (No.Regis) } \\
& =0,991760148-\left(\left(\frac{20}{20} * 0,991760148\right)+\left(\frac{0}{20} * 0\right)\right)
\end{aligned}
$$

Gain (Total, No.Regis) $=0$

Dari hasil tabel 2 Perhitungan Node1 dapat diketahui bahwa atribut dengan gain tertinggi adalah Pembeli, yaitu sebesar 0,811278. Dengan demikian Pembeli dapat menjadi node akar. Ada dua nilai atribut dari Pembeli yaitu Ada dan Tidak Ada, dari kedua nilai atribut tersebut, nilai atribut "Tidak Ada" sudah mengklasifikasikan kasus menjadi 1, yaitu keputusannya TAP, sehingga tidak perlu dilakukan perhitungan lebih lanjut, tetapi untuk nilai atribut "Ada" masih perlu dilakukan perhitungan lagi.

Berdasarkan hasil perhitungan tersebut bisa digambarkan pohon keputusan sementara seperti berikut

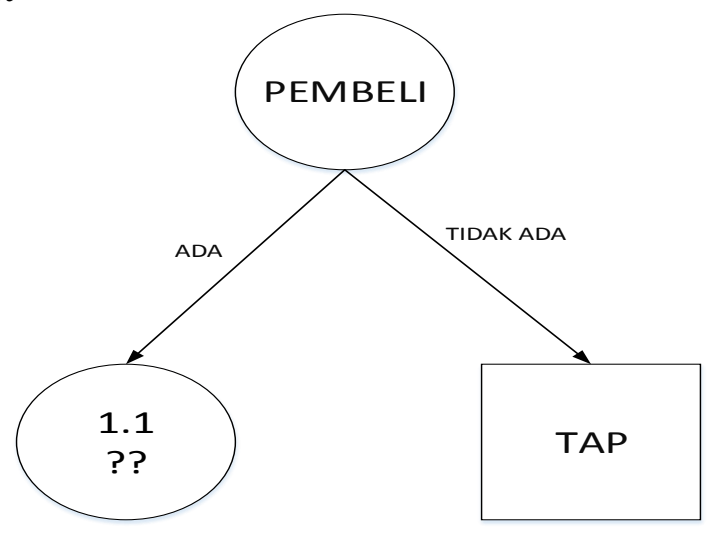

Gambar 4

Pohon Keputusan Hasil Perhitungan Node1 


\section{PERANCANGAN DAN IMPLEMENTASI SISTEM}

Perancangan dalam pembangunan sistem informasi merupakan upaya untuk mengkonstruksi sebuah sistem yang memberikan kepuasan (mungkin informal) akan spesifikasi kebutuhan fungsional, memenuhi target, memenuhi kebutuhan secara implisit atau eksplisit dari segi performansi maupun penggunaan sumber daya, kepuasan batasan pada proses desain dari segi biaya, waktu, dan perangkat.

Hasil dari perancangan sistem pada penelitian ini adalah skema database dan desain antar muka sistem. Skema database adalah model transformasi pemodelan konseptual data yang dibutuhkan sistem ini, Gambar 4 menunjukkan skema database sistem informasi antrian konsultasi.

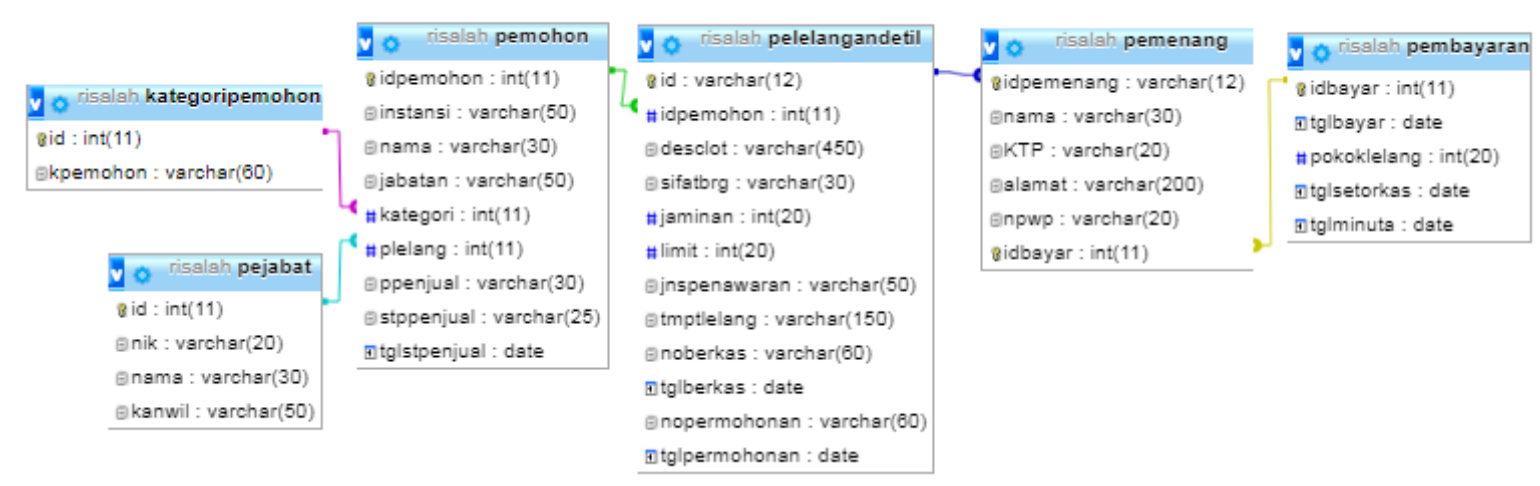

Gambar 5. Skema Database

Perancangan Antarmuka dibuat mulai dari halaman awal, halaman login, halaman input sampai halaman output. Gambar 5 sampai dengan gambar 7 adalah beberapa perancangan antar muka yang dibuat sesuai dengan kebutuhan sistem ini.

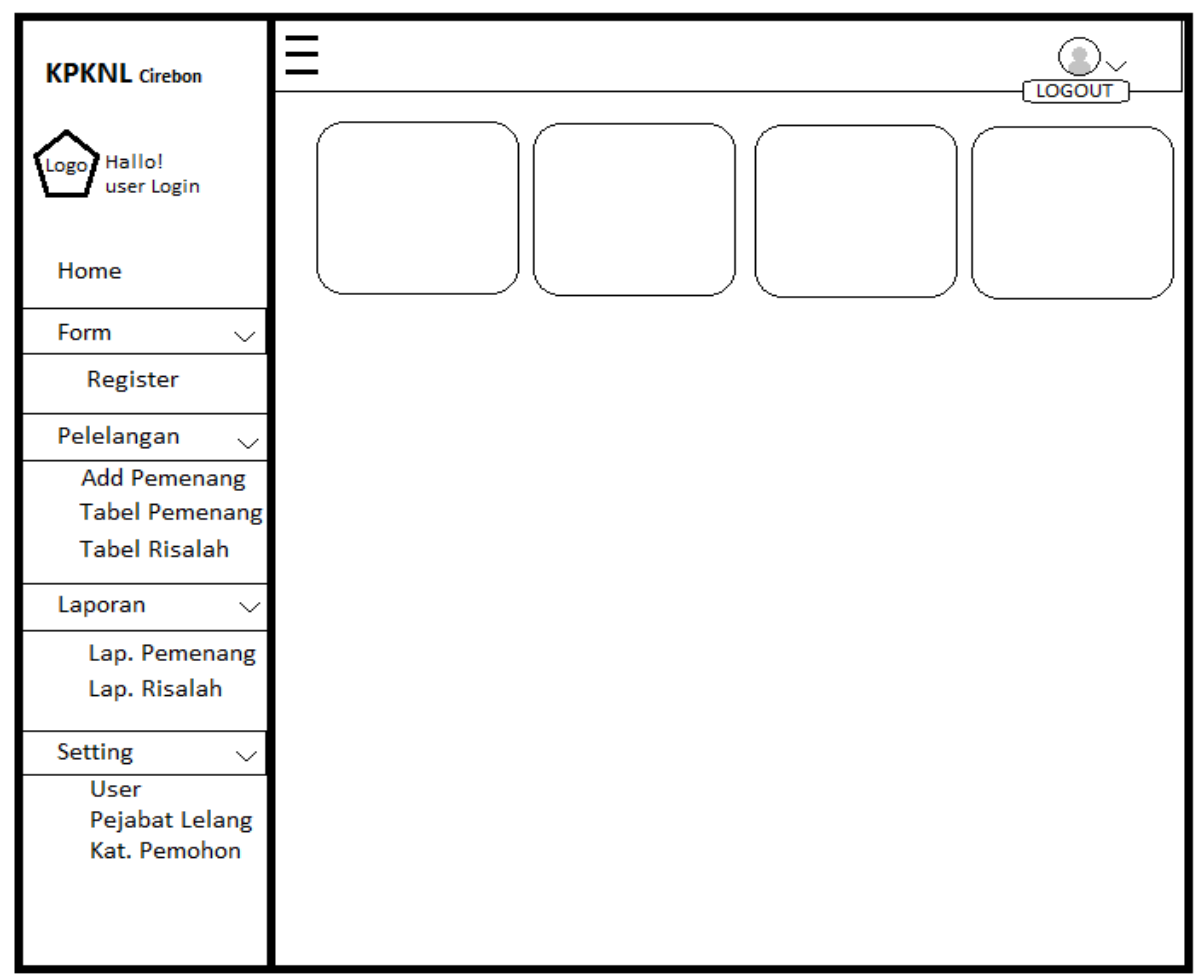

Gambar 6

Halaman Utama User 


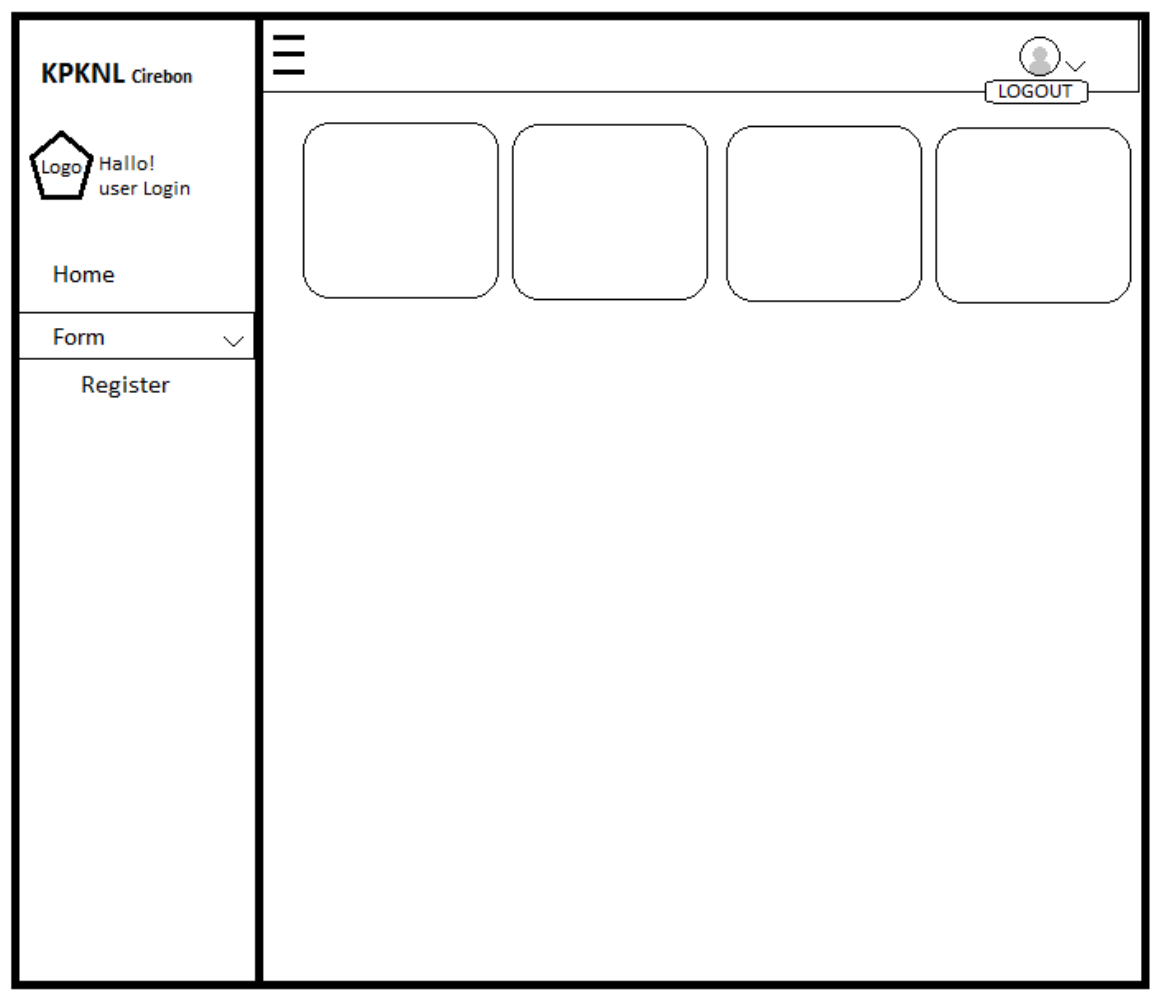

Gambar 7

Halaman Utama Admin Register

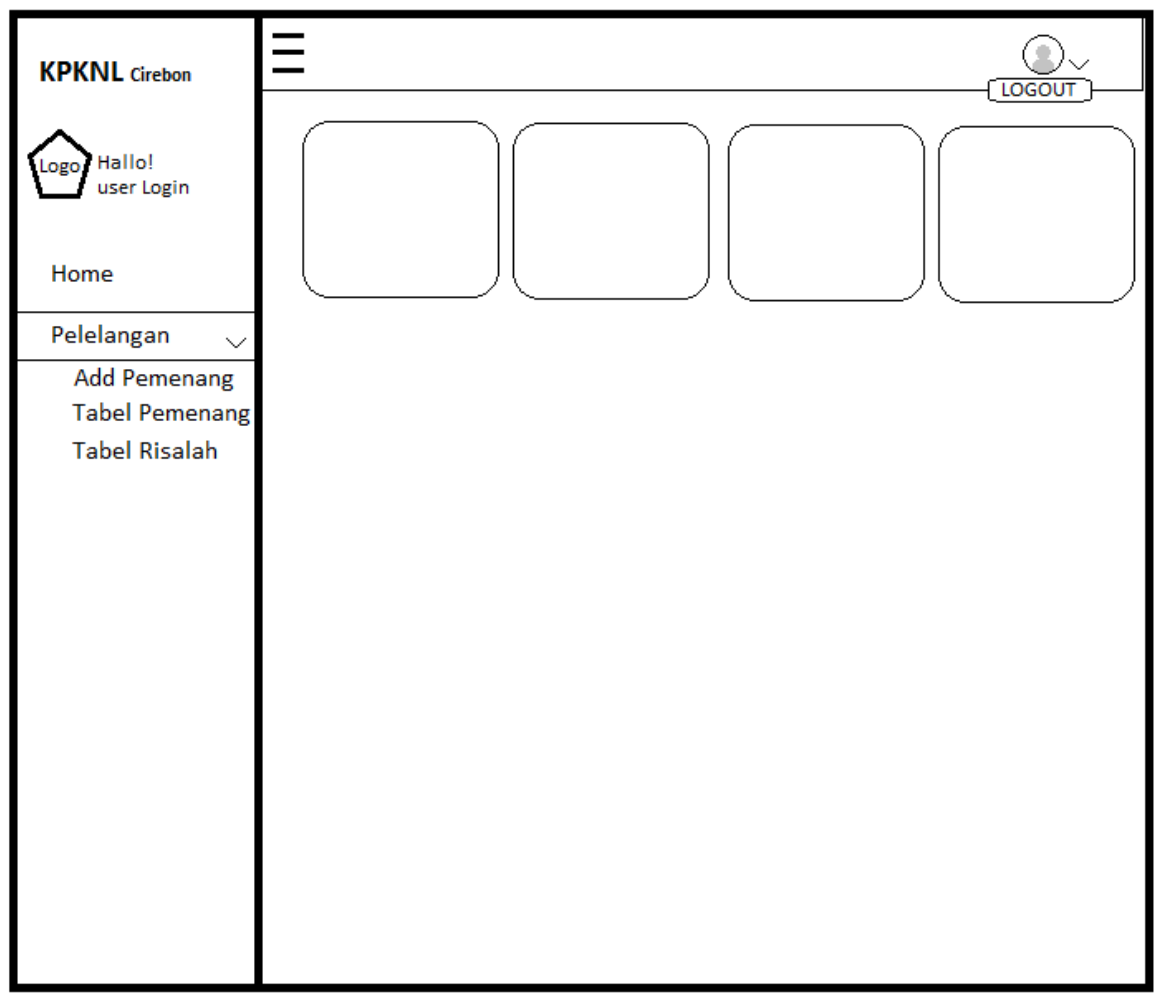

Gambar 8

Halaman Admin Pelelangan 


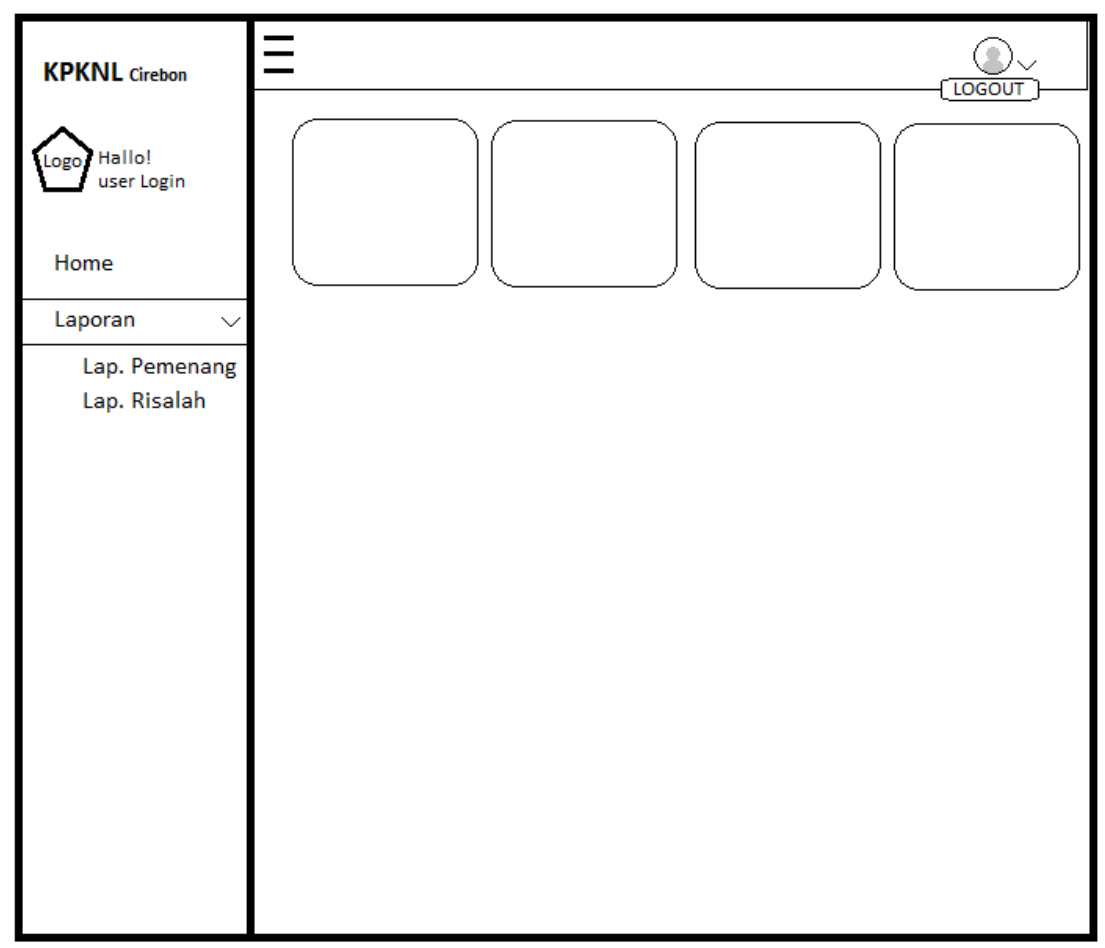

Gambar 9

Halaman Pelaporan

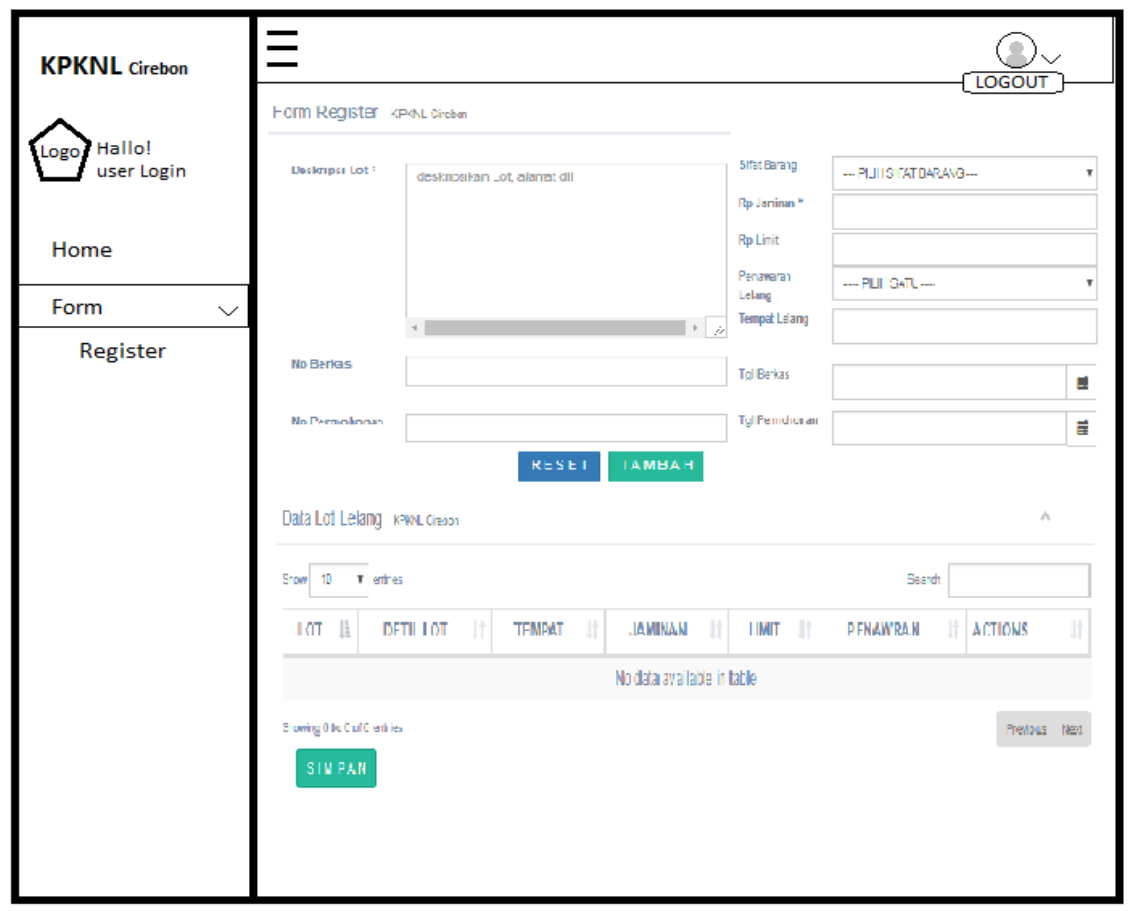

Gambar 10

Halaman Register 


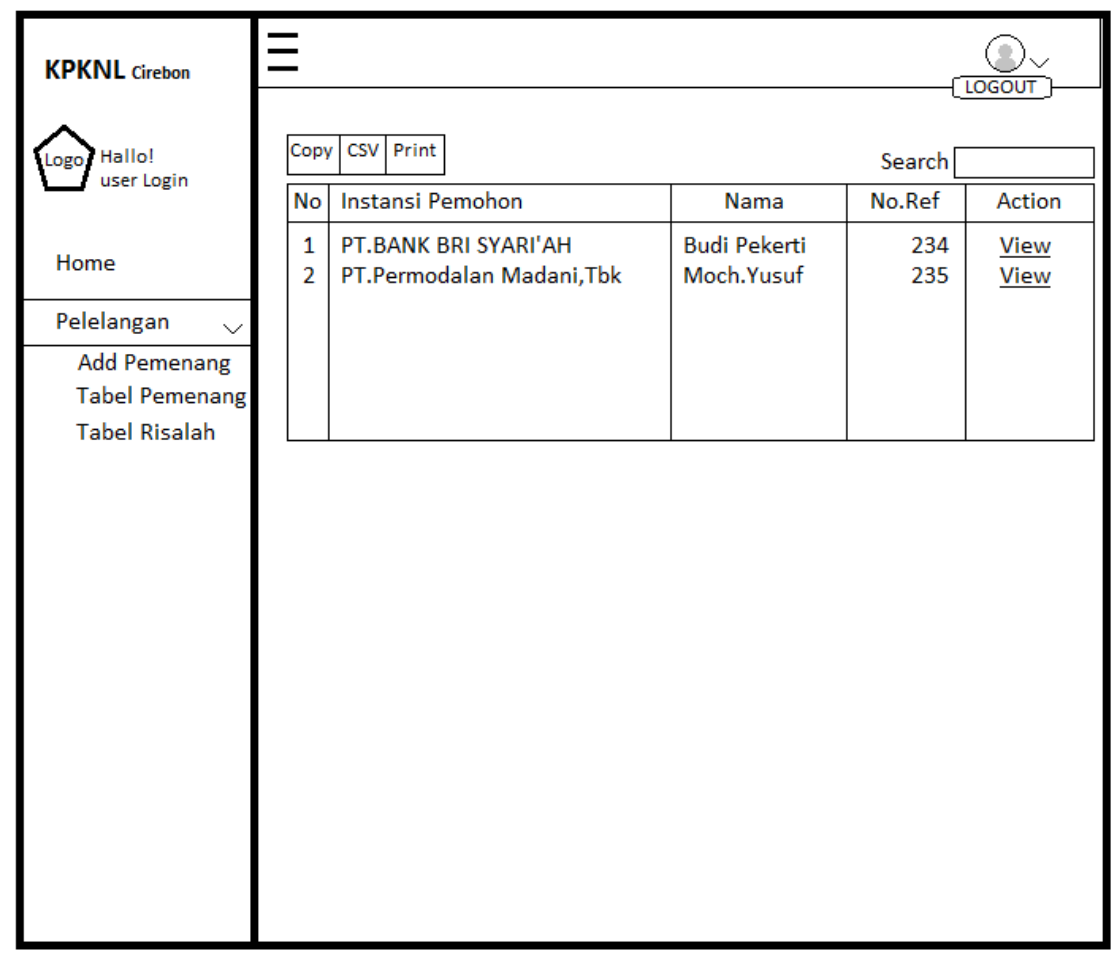

Gambar 11

Halaman Tampilan Pemenang

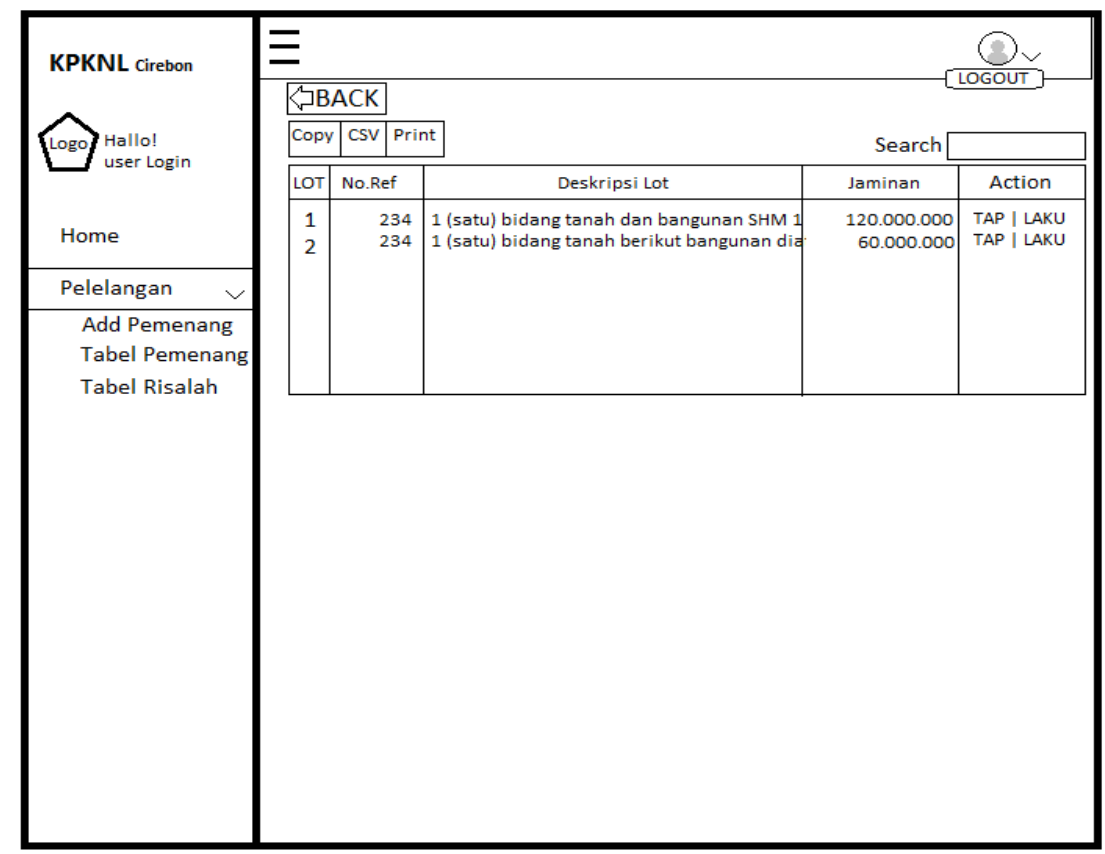

Gambar 12

Tampilan View Pemenang 


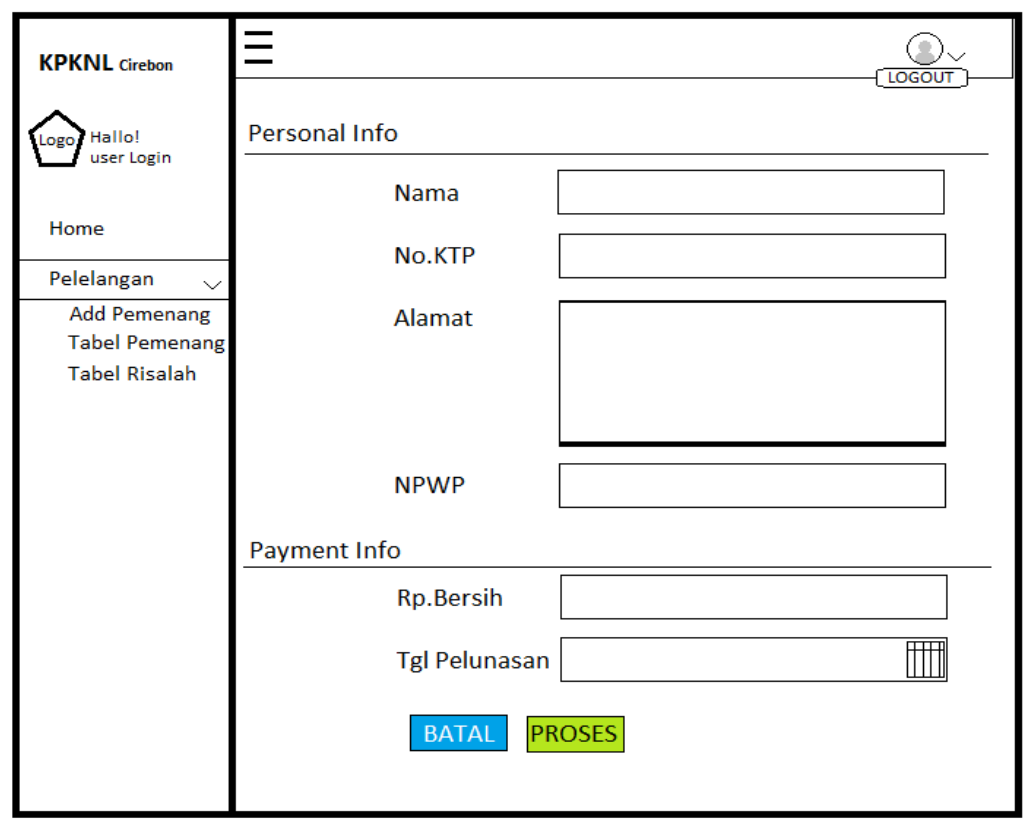

Gambar 13

Tampilan Aksi LAKU Pada Menu Add Pemenang

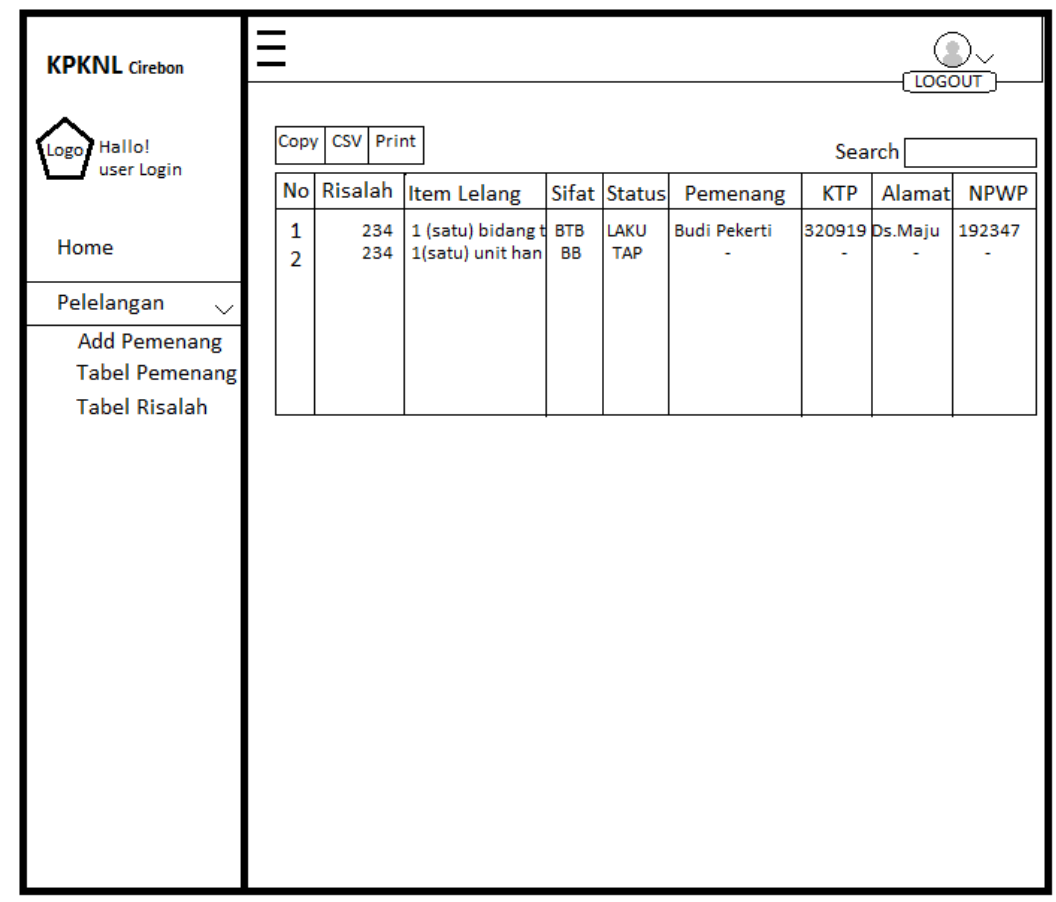

Gambar 14

Tampilan Halaman Menu Tabel Risalah Lelang 


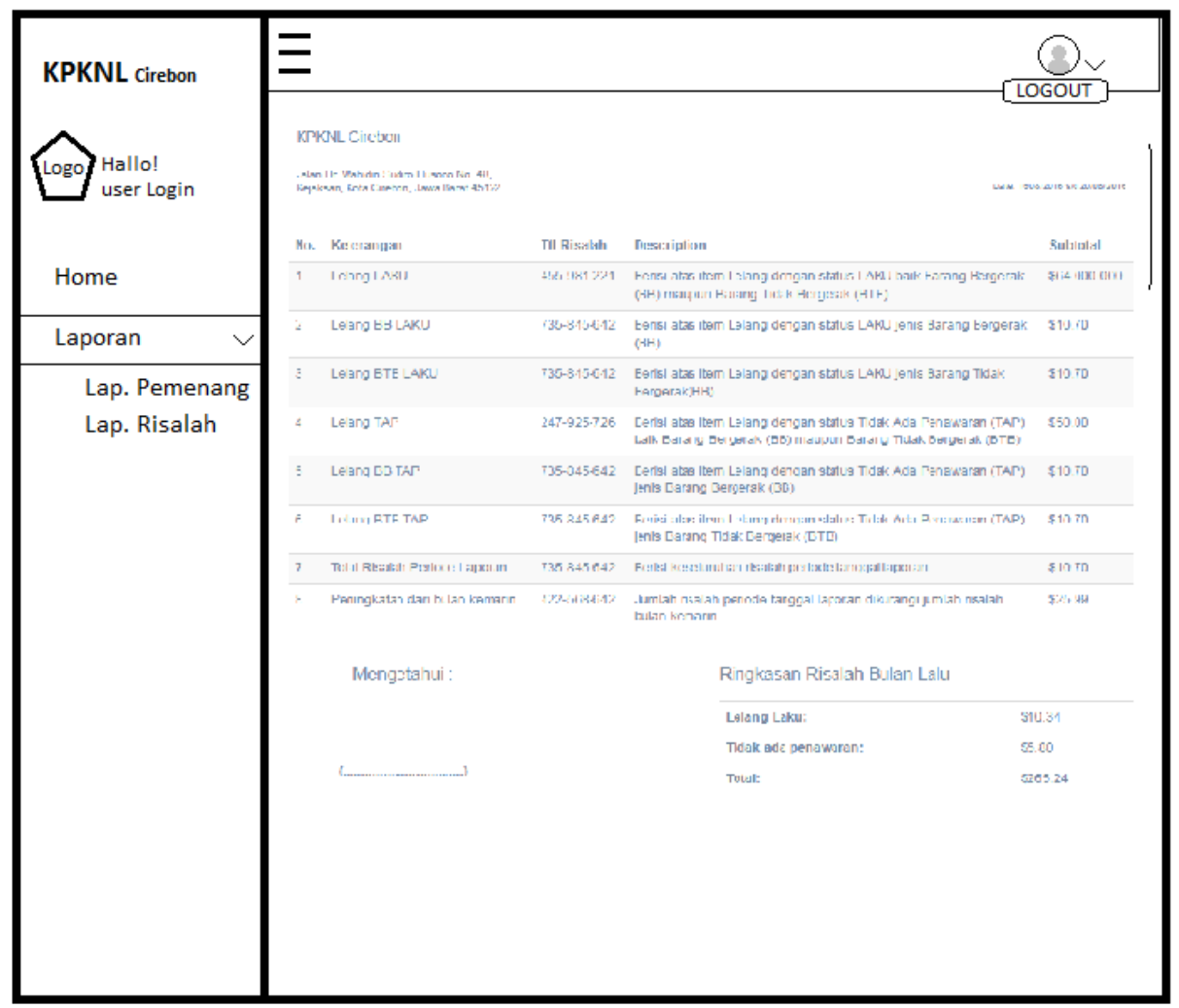

Gambar 15

Tampilan Laporan Risalah Lelang

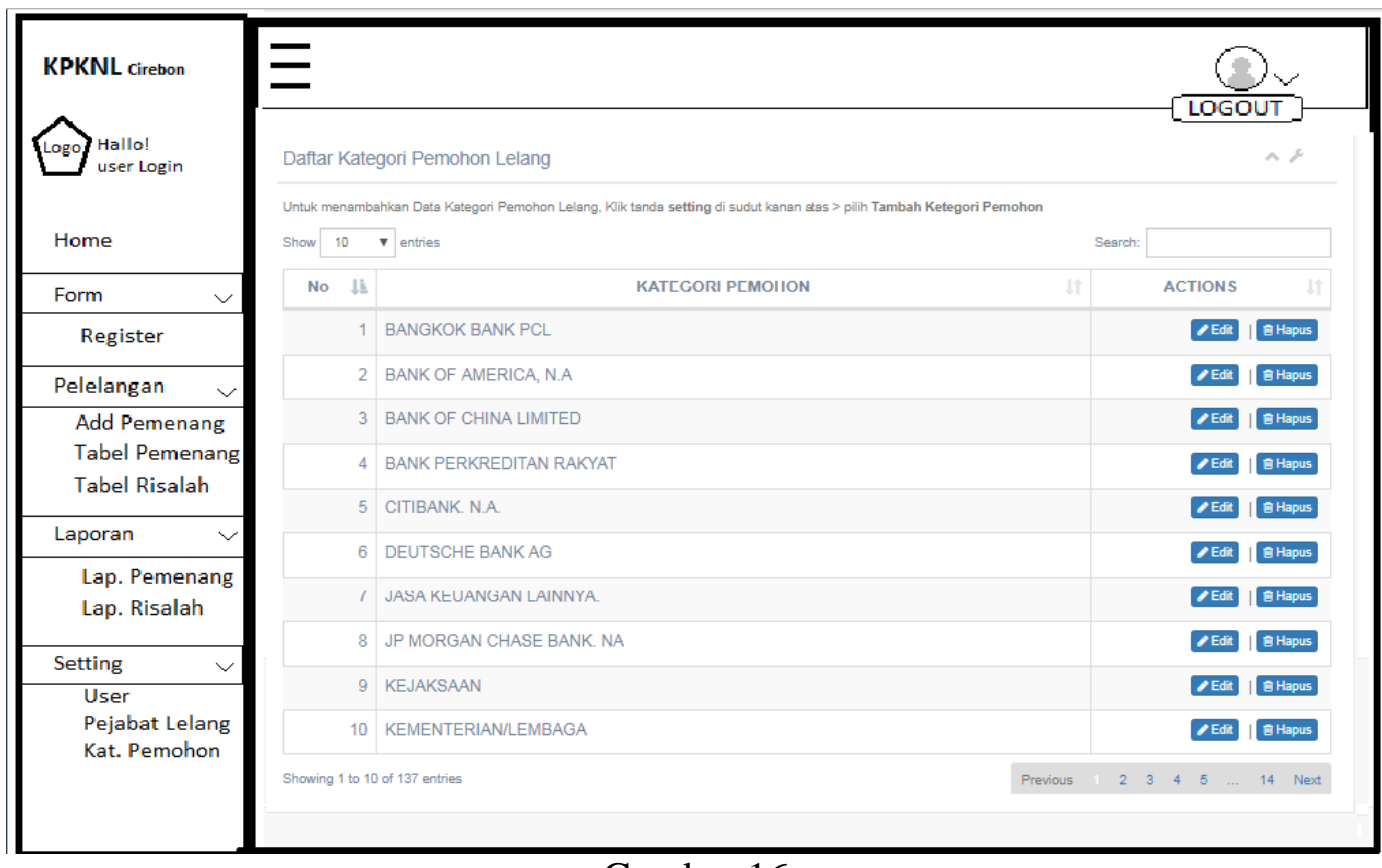

Gambar 16

Halaman Kategori Pemohon Lelang 


\section{KESIMPULAN}

Kesimpulan dari penilitian yang telah dilakukan mengenai Sistem Informasi Risalah Lelang menggunakan Algoritma C45 di Kantor Lelang sebagai berikut :

a. Algoritma C45 dengan metode clustering dapat digunakan dalam sistem informasi risalah lelang untuk pengelompokan dengan kriteriatertentu.

b. Sistem informasi risalah lelang dapat menjadi program yang memberikan pemecahan masalah untuk meningkatkan kinerja dan pelayanan serta memudahkan karyawan dalam melakukan pencarian informasi risalah lelang pada Kantor Pelayanan Kekayaan Negara dan Lelang (KPKNL) kota Cirebon.

\section{REFERENSI}

[1].F. Olaiya, "Application of Data Mining Techniques in Weather Prediction and Climate Change Studies," I.J. Inf. Eng. Electron. Bus., vol. 1, no. February, pp. 5159, 2012.

[2]. W. K. V. Xindong, The Top Ten Algorithms in Data Mining, vol. XXXIII, no. 2. USA: Taylor \& Francis Group, LLC, 2009.

[3]. Leskovec, Jure. Rajaraman, Anand. Jeffrey D. Ullman. , Mining of Massive Datasets, Stanford University,2014,

[4].PERATURAN MENTERI KEUANGAN NOMOR 93 /PMK.06/2010 Tentang Petunjuk Pelaksanaan Lelang, 2010.

[5].Pressman, Roger, S. Software Engineering : A Practitioner's Approach, 7th ed., Mc Graw Hill, 2010.

[6].Suyanto ,Dr., Data Mining Untuk Klasifikasi dan Klasterisasi Data, Penerbit Informatika, 2017. 